\title{
Biotechnological Interventions in Forage Crops-A Review
}

\author{
Rahul Kapoor $^{1 *}$, Tarvinder Pal Singh ${ }^{2}$ and Gaurav Khosla ${ }^{1,2}$ \\ ${ }^{1}$ Department of Plant Breeding and Genetics, Punjab Agricultural University \\ Ludhiana-141004, India \\ ${ }^{2}$ Office of Director (Seeds) Punjab Agricultural University Ludhiana-141004, India \\ *Corresponding author
}

\begin{tabular}{|l|}
\hline Ke y w o r d s \\
Biotechnological \\
interventions, \\
$\begin{array}{l}\text { Forage crops, } \\
\text { Fodder crops }\end{array}$ \\
\hline Article Info \\
\hline $\begin{array}{l}\text { Accepted: } \\
\text { 08 June } 2018 \\
\text { Available Online: } \\
\text { 10 July } 2018\end{array}$ \\
\hline
\end{tabular}

\section{Introduction}

Fodder crops are the plant species that are cultivated and harvested for feeding the animals in the form of forage (cut green and fed fresh), silage (preserved under anaerobic condition) and hay (dehydrated green fodder). In India, the total area under cultivated fodders is 8.3 million ha on individual crop basis. Sorghum amongst the Kharif crops (2.6 million ha) and berseem (Egyptian clover) amongst the Rabi crops (1.9 million ha) occupy about $54 \%$ of the total cultivated fodder cropped area. The area under permanent pastures has been declining over the years and the trend could well continue in the future. Green fodders have an important role in ushering the white revolution in the state. Farmers are cultivating fodder crops in traditional crop rotations which lead to irregular supply of fodder round the year hence the success of dairy industry lies greatly on the availability of green fodder throughout the year, as green fodders are the cheapest 
source of carbohydrates, proteins, vitamins and minerals for dairy animals. Hence by providing sufficient quantities of green fodder instead of costly concentrates and feed to the milch animals the cost of milk production can be substantially reduced.

The average cultivated area in India under fodder production is only $4.4 \%$ of the total cultivated area, but in Punjab, the situation is somewhat better with approximately $10 \%$ of the total cultivated area under fodder crops which is not sufficient. This gap between demand and supply is likely to widen further due to increased pressure to grow more food grains, oilseeds, pulses and commercial crops resulting into a possibility of no further increase in area under forage crops.

Forage production is an important not only for augmenting feed availability but for maintaining the natural resource base through soil stabilization, preventing soil erosion and contributing to soil fertility enrichment. But still, the present fodder supply of 27 $\mathrm{kg} / \mathrm{animal} /$ day is far from satisfactory as for proper feeding about $40 \mathrm{~kg}$ green fodder per animal should be supplied daily. This gap between demand and supply is likely to widen further due to increased pressure to grow more food grains, oilseeds, pulses and commercial crops resulting into a possibility of no increase in area under forage crops. Therefore there is urgent need to improve productivity of fodder and pasture lands by developing new fodder varieties and increased use of wasteland for fodder production.

To improve the genetic potential of fodder crops required variability is not many a time available in the same species but has to be looked for in other species or genera. Thus genetic engineering/transgenics technology may be the remedy to above listed problems because it allows the introduction of foreign genes from unrelated species and the down regulation or up-regulation of endogenous genes, moreover it offers the opportunity to introduce novel genetic variation into plant breeding programmes which otherwise is not possible with intra-specific hybridization and for extending the range of genetic variability beyond that of a single species. The progress and status of the work on genetic engineering/transgenic technology is presented in the following text.

\section{Genetic engineering successes in forages}

Since the production of the first transgenic forage-type tall fescue plants (Wang et al., 1992), tremendous progress has been made in genetic engineering of forage, turf and bioenergy crops in the last two decades. Some of the achievements in genetic engineering of grasses and legumes have been reviewed by Wang and Ge (2006) and Ko“" lliker et al., (2010). In brief, transgenic approaches have been employed to improve these species in the following aspects: significant improvement of in vitro dry matter digestibility in alfalfa, tall fescue and perennial ryegrass (Guo et al., 2001; Chen et al., 2003, 2004; Reddy et al., 2005; Tu et al., 2010); enhanced drought tolerance in alfalfa, white clover, creeping bentgrass and bahiagrass (Paspalum notatum Flugge) (J.-Y. Zhang et al., 2005, 2007; Fu et al., 2007; Jiang et al., 2009, 2010; Xiong et al., 2010); increased phosphorus acquisition in white clover and alfalfa (Ma et al., 2009, 2012); enhanced salt tolerance, cold tolerance or freezing tolerance in perennial ryegrass, tall fescue and creeping bentgrass (Hisano et al., 2004; Hu et al., 2005; Wu et al., 2005; Li et al., 2010); delay or inhibition of floral development in red fescue (Festuca rubra) (Jensen et al., 2004); development of hypoallergenic perennial and Italian ryegrasses (Petrovska et al., 2004); enhanced aluminium tolerance in alfalfa (Tesfaye et al., 2001; Barone et al., 2008); delay of leaf senescence in alfalfa (Calderini et al., 2007; C. Zhou et 
al., 2011); virus-resistant perennial ryegrass and white clover (Xu et al., 2001; Ludlow et al., 2009); increased disease resistance in tall fescue and creeping bentgrass (Fu et al., 2005; Dong et al., 2007, 2008; M. Zhou et al., 2011); improved turf quality in bahiagrass (Agharkar et al., 2007; H. Zhang et al., 2007); accumulation of sulphur-rich protein in subterranean clover (Trifolium subterraneum L.) and tall fescue (Rafiqul et al., 1996; Wang et al., 2001); production of polyhydroxybutyrate in switchgrass (Somleva et al., 2008); increased sugar release in alfalfa and switchgrass (Chen and Dixon, 2007; Jackson et al., 2008; Fu et al., 2011a, b; Saathoff et al., 2011); increased biomass yield in switchgrass (Fu et al., 2012); and a large improvement in bio ethanol production in switchgrass (Fu et al., 2011a). Genetic engineering has greatly contributed to breakthroughs in plant improvement and led to the development of widely grown cultivars in major cash crops (Park et al., 2011). The adoption of transgenic crops in the last 15 years has experienced an 87-fold increase since biotech crops were first commercialized in 1996, making biotech crops the fastest adopted crop technology in history. The accumulated growth areas from 1996 to 2010 exceeded 1 billion hectares (James, 2011). The number of countries planting biotech crops reached 29 in 2010 and the top ten countries each grew more than 1 million hectares. The United States remains the biggest adopter of transgenic crops, with 66.8 million hectares planted in 2010, which represent $45 \%$ of the global biotech area (James, 2011). Despite the wide adoption and the beneficial economic and environmental impacts of transgenic crops, it has been extremely difficult to deregulate and commercialize new transgenic cultivars. The situation is even more complicated in transgenic forage, turf and bioenergy species. One enduring lesson from agricultural biotech is that it is a huge mistake to underestimate bio safety concerns (Stewart,
2007). In this paper, we focus our discussions on the deregulation process of transgenics in the US only. Specific successful and unsuccessful examples will be given to illustrate the process and the complications involved in deregulation of forage and turf.

\section{Gene flow studies in forages}

Pollen is an important vector of gene flow in out crossing species. A simple pollen germination medium was used to assess in vitro viability and longevity of tall fescue and switchgrass pollen (Wang et al., 2004a; Ge et al., 2011). Weather conditions have a large impact on pollen longevity. Under sunny atmospheric conditions, viability of transgenic and nontransgenic tall fescue pollen declined to $5 \%$ in $30 \mathrm{~min}$, with a complete loss of viability in $90 \mathrm{~min}$. Under cloudy atmospheric conditions, viability of tall fescue pollen declined to $5 \%$ after $150 \mathrm{~min}$, with a complete loss of viability in $240 \mathrm{~min}$ (Wang et al., 2004a). Similarly, switchgrass pollen longevity decreased rapidly under sunny atmospheric conditions, with a half-life of less than $4.9 \mathrm{~min}$ and a complete loss of viability in $20 \mathrm{~min}$. Under cloudy atmospheric conditions, the half-life of switchgrass pollen was more than five-fold longer than under sunny conditions, and it took approx. $150 \mathrm{~min}$ to lose viability completely (Ge et al., 2011). In both tall fescue and switchgrass, no difference in pollen viability and longevity was found between transgenic and nontransgenic control plants. As wind-pollinated grasses have a high potential to pass their genes to adjacent plants, pollen flow is not only a concern in transgenics; it has long been a consideration for seed purity of conventional cultivars.

Apomixis is known to exist in many warmseason grasses, such as Poa and Paspalum species. Apomictic reproduction mode is characterized by embryo development, which 
is independent of fertilization of the egg cell, but requires fertilization with compatible pollen to produce the endosperm (Sandhu et al., 2010). Transgenic Kentucky bluegrass was used as a pollen donor to quantify intra- and interspecific pollen mediated gene flow. Twenty-five sexual and facultative apomictic Poa species were used as pollen receptor and placed at 0,13 and $53 \mathrm{~m}$ distances from the transgenic materials. Overall hybrid frequency was $0.048 \%$ and hybrid frequency at the $0-\mathrm{m}$ distance was $0.53 \%$ (Johnson et al., 2006).

To quantify gene flow from apomictic tetraploid bahiagrass (Paspalum notatum Flugge) to tetraploid or diploid bahiagrass, the glufosinate-resistant apomictic bahiagrass was grown at close proximity $(0.5-3.5 \mathrm{~m})$ with non-transgenic cultivars. Average gene transfer between transgenic apomictic, tetraploid and sexual diploid bahiagrass was $0.03 \%$. Average gene transfer between transgenic apomictic tetraploid and nontransgenic, apomictic tetraploid bahiagrass was $0.17 \%$ (Sandhu et al., 2010). While not providing complete transgene containment, gene transfer between apomictic species occurs at low frequency and over short distances (Johnson et al., 2006; Sandhu et al., 2010). In a landscape-level of study for 'Roundup Ready' creeping bentgrass, it was found that most of the gene flow occurred within $2 \mathrm{~km}$ in the direction of prevailing winds. The maximal gene flow distances observed were 21 and $14 \mathrm{~km}$ in sentinel and resident plants, respectively, that were located in Alfalfa and white clover are predominantly pollinated by insects. A large-scale field study of 'Roundup Ready' alfalfa showed that pollen-mediated gene flow diminished with increasing distance from the source.

Gene flow is a natural event that happens all the time, but the introduction of modern biotechnology has brought new attention to this natural process and raised ecological, economic as well as intellectual property issues for scientists and policymakers to consider. A main focus in risk assessment research should be placed on the consequences of transgene flow. The phenotypes of transgenic plants and their safety in the environment, not the method used to produce them, should be the main focus of risk analyses and regulatory concern (Bradford $e t$ al., 2005).

\section{Deregulation of 'roundup ready' alfalfa}

Although significant progress has been made in the genetic engineering of forage, turf and bioenergy species, to date, the only deregulated crop is 'Roundup Ready' alfalfa. The deregulation process is lengthy and complicated. The trait was obtained by transgenic expression of the 5enolpyruvylshikimate-3-phosphate synthase (EPSPS) gene. The gene was derived from the CP4 strain of Agrobacterium tumefaciens. The transgenic alfalfa plants were obtained by Agrobacterium-mediated transformation. The non-selective herbicide glyphosate inhibits an essential step in aromatic amine synthesis in plants by blocking the action of the natural EPSPS enzymes already present in the plant. However, the CP4 EPSPS protein is not inhibited by glyphosate; thus any plant expressing sufficient levels of this protein is tolerant to glyphosate application. The 'Roundup Ready' alfalfa is also called glyphosate-tolerant (GT) alfalfa.

\section{Herbicide-tolerant kentucky bluegrass}

The Scotts Company produced new glyphosate-tolerant transgenic Kentucky bluegrass without using plant pest components. Specifically, the transgenic plants were produced by biolistic transformation, without involving Agrobacterium transformation or any other plant pest regulated under the Plant Protection 
Act. The herbicide resistance gene EPSPS is from Arabidopsis thaliana, the ubiquitin promoter is from rice, the actin intron is from rice and the alcohol dehydrogenase $3^{\prime}$ untranslated region is from maize. The Animal and Plant Health Inspection Service (APHIS) defines a 'regulated article' as: any organism which has been altered or produced through genetic engineering, if the donor organism, recipient organism, or vector or vector agent belongs to any genera or taxa designated in $\S$ 340.2 and meets the definition of plant pest, or is an unclassified organism and/or an organism whose classification is unknown, or any product which contains such an organism, or any other organism or product altered or produced through genetic engineering which the administrator determines is a plant pest or has reason to believe is a plant pest.

Table.1

\begin{tabular}{|l|l|l|}
\hline Crop & Trait Targeted & Reference \\
\hline $\begin{array}{l}\text { alfalfa, tall fescue and } \\
\text { perennial ryegrass }\end{array}$ & $\begin{array}{l}\text { In-vitro dry matter } \\
\text { digestibility }\end{array}$ & $\begin{array}{l}\text { Guo } \text { et al., 2001; Chen } \text { et al., 2003, } \\
\text { 2004; Reddy } \text { et al., 2005; Tu } \text { et al., } \\
\text { 2010 }\end{array}$ \\
\hline $\begin{array}{l}\text { alfalfa, white clover, } \\
\text { creeping bentgrass and } \\
\text { bahiagrass }\end{array}$ & Enhanced drought tolerance & $\begin{array}{l}\text { J.-Y. Zhang } \text { et al., 2005, 2007; Fu } \text { et } \\
\text { al., 2007; Jang } \text { et al., 2009, 2010; } \\
\text { Xiong } \text { et al., 2010 }\end{array}$ \\
\hline white clover and alfalfa & $\begin{array}{l}\text { Increased phosphorus } \\
\text { acquisition }\end{array}$ & Ma et al., 2009, 2012 \\
\hline $\begin{array}{l}\text { perennial ryegrass, tall } \\
\text { fescue and creeping } \\
\text { bentgrass }\end{array}$ & $\begin{array}{l}\text { Enhanced salt tolerance, cold } \\
\text { tolerance or freezing } \\
\text { tolerance }\end{array}$ & $\begin{array}{l}\text { Hisano } \text { et al., 2004; Hu } \text { et al., 2005; } \\
\text { Wu } \text { et al., 2005; Li } \text { et al., 2010 }\end{array}$ \\
\hline Tall fescue & $\begin{array}{l}\text { Delay or inhibition of floral } \\
\text { development }\end{array}$ & Jensen et al., 2004 \\
\hline alfalfa & $\begin{array}{l}\text { Enhanced aluminium } \\
\text { tolerance }\end{array}$ & $\begin{array}{l}\text { Tesfaye } \text { et al., 2001; Barone } \text { et al., } \\
2008\end{array}$ \\
\hline alfalfa & Delay of leaf senescence & $\begin{array}{l}\text { Calderini } \text { et al., 2007; C. Zhou } \text { et } \\
\text { al., 2011 }\end{array}$ \\
\hline $\begin{array}{l}\text { perennial ryegrass and } \\
\text { white clover }\end{array}$ & Virus-resistance & Xu et al., 2001; Ludlow et al., 2009 \\
\hline $\begin{array}{l}\text { tall fescue and creeping } \\
\text { bentgrass }\end{array}$ & Increased disease resistance & $\begin{array}{l}\text { Fu } \text { et al., 2005; Dong } \text { et al., 2007, } \\
\text { 2008; M. Zhou } \text { et al., 2011 }\end{array}$ \\
\hline bahiagrass & Improved turf quality & $\begin{array}{l}\text { Agharkar } \text { } \text { et al., 2007; H. Zhang } \text { et } \\
\text { al., 2007 }\end{array}$ \\
\hline $\begin{array}{l}\text { subterranean clover and tall } \\
\text { fescue }\end{array}$ & $\begin{array}{l}\text { Accumulation of sulphur-rich } \\
\text { protein }\end{array}$ & $\begin{array}{l}\text { Rafiqul } \text { et al., 1996; Wang } \text { et al., } \\
\text { 2001 }\end{array}$ \\
\hline alfalfa and switchgrass & increased sugar release & $\begin{array}{l}\text { Chen and Dixon, 2007; Jackson } \text { et } \\
\text { al., 2008; Fu } \text { et al., 2011a, b; } \\
\text { Saathoff } \text { et al., 2011 }\end{array}$ \\
\hline switchgrass & $\begin{array}{l}\text { improvement in bio ethanol } \\
\text { production }\end{array}$ & Fu et al., 2011 \\
\hline
\end{tabular}




\section{Intragenesis and cisgenesis}

One of the public concerns about transgenic crops relates to the mingling of genetic materials among distantly related organisms. New molecular strategies have been designed to address the issue. Intragenesis (Rommens et al., 2004, 2007) or cisgenesis (Schouten et al., 2006a, b) refers to the introduction of one or more genes that are derived from the target species itself or species that are sexually compatible with the target species. Cisgenesis is more restrictive in that it refers to the transfer of a complete DNA copy of a natural gene, including its promoter and terminator (Schouten and Jacobsen, 2008). It is obvious that intragenic or cisgenic plants are closer to their natural counterparts than the abovementioned Kentucky blue grass.

Conventional breeding employs methods such as introgression and mutagenesis to modify a plant genome randomly and, as a result, create genetic variation (Rommens et al., 2007). In the case of intragenic or cisgenic plants, the gene of interest, together with its regulatory sequences, has been present in the species or in a sexually compatible relative for centuries (Schouten et al., 2006a). Therefore, the gene pool exploited by intragenesis and cisgenesis is identical to the gene pool available for traditional breeding (Holme et al., 2012).

Furthermore, no changes in fitness occur that would not happen through either conventional breeding or natural gene flow. Intragenic or cisgenic plants carry no additional risks such as effects on non-target organisms or soil ecosystems, toxicity or a possible allergy risk for GM food or feed -other than those that are also incurred by conventional breeding (Schouten et al., 2006a). By avoiding the transfer of foreign or unknown DNA, crops developed through intragenesis or cisgenesis mimic the conventionally bred cultivars. In fact, they have much less gene shuffling than the conventional cultivars. By eliminating various potential risk factors, the intragenic or cisgenic method represents a relatively safe approach to crop improvement (Rommens et al., 2007). Therefore, it has been argued that intragenic or cisgenic plants should be treated as conventionally bred plants (Schouten et al., 2006a; Rommens et al., 2007). Considering gene flow and other biosafety issues in forage, turf and bioenergy crops, the intragenic or cisgenic approach may provide a cost-effective way for genetic engineering of these species.

\section{Improving lysine and methionine levels in forage crops}

In forage crops the main consumed part is the vegetative tissue, and therefore efforts to increase the essential amino acid content in vegetative tissues were mainly conducted by constitutive expression of recombinant constructs expressing seed vacuolar storage proteins, fused to the $35 \mathrm{~S}$ promoter. These storage proteins which stably accumulate in seeds vacuoles, failed to accumulate in the protease-rich vegetative vacuoles, due to their efficient degradation (Saalbach et al., 1994). Preventing the trafficking of the seed storage proteins from the endoplasmic reticulum (ER) to the vegetative vacuole by engineering of an ER retention signal (KDEL) into the Cterminus of these proteins only partially solved their stability problems (Khan et al., 1996; Tabe et al., 1995; Wandelt et al., 1992). More successful results were obtained by using two methionine-rich seed storage proteins of maize, namely, the $15-\mathrm{kDa} \beta$-zein and the $10-\mathrm{kDa} \delta$-zein, which naturally accumulate in ER-derived protein bodies (Shotwell and Larkins, 1989), Maize $\beta$-zein and $\delta$-zein genes, constitutively expressed alone in transgenic tobacco plants, accumulated in novel ER-derived protein bodies and were moderately stable (Bagga $e t$ al., 1995). Co-expression of the two proteins 
together significantly increased their stability (Bagga et al., 1997). Stability problems associated with the expression of seed storage proteins in vegetative tissues suggest that expression of genes for other types of nutritionally balanced proteins should also be tried. Inasmuch as a number of plants also naturally accumulate vegetative storage proteins (VSPs) to high levels inside vegetative vacuoles (Staswick, 1994), such proteins may be better targets for nutritional improvement of forage crops than seed storage proteins. VSPs may also have additional beneficial effects, such as enhancement of shoot regrowth after cutting of forage crops. Guenoune and co-workers, 1999 overexpressed the soybean VSP $\alpha$ gene, fused to the Cauliflower mosaic virus (CaMV) 35S promoter, in transgenic tobacco plants. This protein was highly stable in vacuoles of both vegetative and seed tissues. The level of the soybean VSP $\alpha$ ranged between 2 and $6 \%$ of the soluble proteins in leaves of the transgenic plants, causing a significant increase of total soluble lysine by about $15 \%$. This suggests that VSPs can serve as excellent protein sources for improving the nutritional quality of forage crops.

Plant improvement is needed to enhance our ability to produce food, feed, fibre and fuel and to ensure we have a safe, liveable environment. Ideally, our plant improvement efforts would be done in a way that is in harmony with the environment (Brummer et $a l ., 2011)$. In addition to their main product or function, forages, turf and bioenergy species have positive effects on farming systems and on the environment. For example, including forage crops, such as alfalfa, into a crop rotation with corn and soybean had both environmental and economic benefits (Olmstead and Brummer, 2008). The modern plant improvement technologies developed for genetic manipulation of various forage, turf and bioenergy species have opened up new opportunities for breeding these crops, which may help make them more valuable to cropping systems and hence more likely to become a component of them, bringing along their multifunctional benefits.

Transgenesis, including nuclear transformation as well as intragenesis, cisgenesis and chloroplast transformation, provides a rapid means for plant improvement, and should be among the technologies being used as we attempt to develop improved crops to be included into sustainable cropping or landscape systems (Ronald, 2011). The major challenge now is how to apply the technology to generate new genetic variability in a way that satisfies regulatory requirements. The development of an EIS for alfalfa and the deregulation of herbicide-tolerant alfalfa paved the way for future transgenic improvement of this important forage legume crop. For grasses, the development of intragenic or cisgenic lines is likely to be the first practical step toward deregulation.

Despite various concerns, major transgenic crops have been widely cultivated and intensively consumed in the last 16 years with no documented cases of adverse effects on health or the environment. A streamlined regulatory system, designed to catch obvious hazards but not prevent entry into the marketplace by small companies and nonprofit organizations, needs to be developed. By efficient incorporation of novel germplasm into applied breeding programmes, transgenic cultivars have the potential to play a critical role in fulfilling the increasing demand for animal products and renewable fuels in the 21 st century, and in conjunction with ecologically driven farming practices, leading to an economically and environmentally sustainable agricultural system. 


\section{References}

Agharkar, M., Lomba, P., Altpeter, F., Zhang, H., Kenworthy, K. and Lange, T. 2007. Stable expression of AtGA2ox1 in a low-input turfgrass (Paspalum notatum Flugge) reduces bioactive gibberellin levels and improves turf quality under field conditions. Plant Biotechnology Journal 5: 791-801.

Bagga, S., Adams, H., Kemp, J. D. and Sengupta-Gopalan, C. 1995. Accumulation of 15-kilodalton zein in novel protein bodies in transgenic tobacco. Plant Physiol 107: 11-23.

Bagga, S., Adams, H. P., Rodriguez, F. D., Kemp, J. D. and Sengupta-Gopalan, C. 1997. Coexpression of the maize $\delta$ zein and $\beta$-zein genes results in stable accumulation of $\delta$-zein in endoplasmic reticulum derived protein bodies formed by $\beta$-zein. Plant Cell 9: 16831696.

Barone, P., Rosellini, D., LaFayette, P., Bouton, J., Veronesi, F. and Parrott, W. 2008. Bacterial citrate synthase expression and soil aluminum tolerance in transgenic alfalfa. Plant Cell Reports 27: 893901.

Bradford, K.J., Van Deynze, A., Gutterson, N., Parrott, W. and Strauss, S.H. 2005. Regulating transgenic crops sensibly: lessons from plant breeding, biotechnology and genomics. Nature Biotechnology 23: 439-444.

Brummer, E.C., Barber, W.T., Collier, S.M., Cox T.S., Jhonson R, Murray S.C., Olsen R.T., Pratt R.C., and Thro A.M. 2011. Plant breeding for harmony between agriculture and the environment. Frontiers in Ecology and the Environment 9: 561-568.

Calderini, O., Bovone, T., Scotti, C., Pupilli, F., Piano, E. and Arcioni, S. 2007. Delay of leaf senescence in Medicago sativa transformed with the ipt gene controlled by the senescence-specific promoter SAG12. Plant Cell Reports 26: 611-615.

Chen, F. and Dixon, R.A. 2007. Lignin modification improves fermentable sugar yields for biofuel production. Nature Biotechnology 25: 759-761.

Chen, L., Auh, C., Dowling, P., Bell J., Chen F., Hopkins A., Dixon R.A., and Wang Z.Y. 2003. Improved forage digestibility of tall fescue (Festuca arundinacea) by transgenic downregulation of cinnamyl alcohol dehydrogenase. Plant Biotechnology Journal 1: 437-449.

Chen, L., Auh, C., Dowling, P., Bell, J., Lehmann, D. and Wang, Z-Y. 2004. Transgenic down-regulation of caffeic acid O-methyltransferase (COMT) led to improved digestibility in tall fescue (Festuca arundinacea). Functional Plant Biology 31: 235-245.

Dong, S., Shew, H.D., Tredway, L.P., lu J., Sivamani E., Miller E.S., and Qu R. 2008. Expression of the bacteriophage T4 lysozyme gene in tall fescue confers resistance to gray leaf spot and brown patch diseases. Transgenic Research 17: 47-57.

Fu, C., Mielenz, J.R., Xiao, X., Ge Y., Hamilton C.Y., Rodriguez M Jr., Chen F., Foston M., Ragauskas A., Bouton J., Dixon R.A., Wang Z.Y. 2011 a. Genetic manipulation of lignin reduces recalcitrance and improves ethanol production from switchgrass. Proceedings of the National Academy of Sciences of the USA 108: 38033808.

Chunxiang Fu., Xirong Xiao., Yajun Xi., Yaxin Ge., Fang Chen., Joseph Bouton., Richard A. Dixon., Zeng-Yu Wang 2011b. Downregulation of cinnamyl alcohol dehydrogenase (CAD) leads to improved 
saccharification efficiency in switchgrass. Bioenergy Research 4: 153-164.

Fu, C., Sunkar, R., Zhou, C., Shen H, Zhang JY, Matts J, Wolf J, Mann DG, Stewart CN Jr, Tang Y, Wang ZY 2012. Overexpression of miR156 in switchgrass (Panicum virgatum L.) results in various morphological alterations and leads to improved biomass production. Plant Biotechnology Journal. 10(4): 443452.

Fu, D., Tisserat, N.A., Xiao, Y., Settle, D., Muthukrishnan, S. and Liang, G.H. 2005. Overexpression of rice TLPD34 enhances dollar-spot resistance in transgenic bentgrass. Plant Science 168: 671-680.

Fu, D., Huang, B., Xiao, Y., Muthukrishnan, S. and Liang, G. 2007. Overexpression of barley hval gene in creeping bentgrass for improving drought tolerance. Plant Cell Reports 26: 467 477.

Ge, Y., Fu, C., Bhandari, H., Bouton, J., Brummer, E.C. and Wang, Z-Y. 2011. Pollen viability and longevity of switchgrass (Panicum virgatum L.). Crop Science 51: 2698-2705.

Guenoune, D., Amir, R., Ben-Dor, B., Wolf, S. and Galili, S. 1999. A soybean vegetative storage protein accumulates to high levels in various organs of transgenic tobacco plants. Plant Sci 145: 93-98.

Guo, D.J., Chen, F., Wheeler, J., Winder J., Selman s., Peterson M. and Dixon R.A. 2001. Improvement of in-rumen digestibility of alfalfa forage by genetic manipulation of lignin $\mathrm{O}$ methyltransferases. Transgenic Research 10: 457-464.

Hisano, H., Kanazawa, A., Kawakami, A., Yoshida, M., Shimamoto, Y. and Yamada, T. 2004. Transgenic perennial ryegrass plants expressing wheat fructosyltransferase genes accumulate increased amounts of fructan and acquire increased tolerance on a cellular level to freezing. Plant Science 167:861-868.

Hu, Y., Jia, W., Wang, J., Zhang, Y., Yang, L. and Lin, Z. 2005. Transgenic tall fescue containing the Agrobacterium tumefaciens ipt gene shows enhanced cold tolerance. Plant Cell Reports 23: 705-709.

Jackson, L., Shadle, G., Zhou, R., Nakashima, J., Chen, F. and Dixon, R. 2008. Improving saccharification efficiency of alfalfa stems through modification of the terminal stages of monolignol biosynthesis. Bioenergy Research 1: 180-192.

James, C. 2011. Global Status of Commercialized Biotech/GM Crops: 2010. The International Service for the Acquisition of Agri-biotech Applications (ISAAA). http://www.isaaa.org.

Jensen, C.S., Salchert, K., Gao, C., Andersen, C., Didion, T. and Nielsen, K.K. 2004. Floral inhibition in red fescue (Festuca rubra L.) through expression of a heterologous flowering repressor from Lolium. Molecular Breeding 13: 37-48.

Jiang, Q., Zhang, J-Y., Guo, X., Monteros, M. and Wang, Z-Y. 2009. Physiological characterization of transgenic alfalfa (Medicago sativa) plants for improved drought tolerance. International Journal of Plant Sciences 170: 969978.

Jiang, Q., Zhang, J., Guo, X., Bedair M., Sumner L., Bouton J., and Wang Z. 2010. Improvement of drought tolerance in white clover (Trifolium repens) by transgenic expression of a transcription factor gene WXP1. Functional Plant Biology 37: 157-165. 
Johnson, P.G., Larson, S.R., Anderton, A.L., Patterson, J.T., Cattani, D.J. and Nelson, E.K. 2006. Pollen-mediated gene flow from Kentucky bluegrass under cultivated field conditions. Crop Science 46: 1990-1997.

Khan, M.R.I., Ceriotti, A., Tabe, L., Aryan, A., McNabb, W., Moore, A., Craig, S.D.S. and Higgins, T.J.V. 1996. Accumulation of a sulfur-rich seed albumin from sunflower in the leaves of transgenic subterranean clover (Trifolium subterraneum L). Transgenic Res 5: 179-185.

Ko“lliker, R., Rosellini, D., Wang, Z-Y. 2010. Development and application of biotechnological and molecular genetic tools. In: Boller B, Posselt UK, Veronesi F. eds. Handbook of plant breeding: fodder crops and amenity grasses. New York: Springer Science+Business Media, 89-113.

Li, Z., Baldwin, C.M., Hu, Q., Liu, H. and Luo, H. 2010. Heterologous expression of Arabidopsis $\mathrm{H}+-$ pyrophosphatase enhances salt tolerance in transgenic creeping bentgrass (Agrostis stolonifera L.). Plant, Cell \& Environment 33: 272 289.

Ludlow, E.J., Mouradov, A. and Spangenberg, G.C. 2009. Posttranscriptional gene silencing as an efficient tool for engineering resistance to white clover mosaic virus in white clover (Trifolium repens). Journal of Plant Physiology 166: 1557-1567.

Ma, X-F., Wright, E., Ge, Y., Bell, J., Xi, Y., Bouton, J.H. and Wang. Z-Y. 2009. Improving phosphorus acquisition of white clover (Trifolium repens L.) by transgenic expression of plant-derived phytase and acid phosphatase genes. Plant Science 176: 479-488.

Ma, X-F., Tudor, S., Butler, T., Ge Y., Xi Y.,
Bouton J., Harrison M., and Wang Z.Y. 2012. Transgenic expression of phytase and acid phosphatase genes in alfalfa (Medicago sativa) leads to improved phosphate uptake in natural soils. Molecular Breeding. 30 (1): 377-391.

Olmstead, J. and Brummer, E.C. 2008. Benefits and barriers to perennial forage crops in Iowa corn and soybean rotations. Renewable Agriculture and Food Systems 23: 97-107.

Park, J.R., McFarlane, I., Phipps, R.R. and Ceddia, G. 2011. The role of transgenic crops in sustainable development. Plant Biotechnology Journal 9: 2-21.

Petrovska, N., Wu, X., Donato, R., Zengyu W., Eng-Kok O., Elizabeth J., John F., Michael E., Alessandro S., Robyn O. And German S. 2004. Transgenic ryegrasses (Lolium spp.) with downregulation of main pollen allergens. Molecular Breeding 14: 489-501.

Rafiqul, M., Khan, I., Ceriotti, A., Linda T., Arun A., Warren M., Andrew M., Struat C., Donals S. And Thomas J.V.H. 1996. Accumulation of a sulphur-rich seed albumin from sunflower in the leaves of transgenic subterranean clover (Trifolium subterraneum L.). Transgenic Research 5: 179-185.

Reddy, M.S.S., Chen, F., Shadle, G., Jackson, L., Aljoe, H. and Dixon, R.A. 2005. Targeted down-regulation of cytochrome P450 enzymes for forage quality improvement in alfalfa (Medicago sativa L.). Proceedings of the National Academy of Sciences of the USA 102: 16573-16578.

Rommens, C.M., Haring, M.A., Swords, K., Davies, H.V. and Belknap, W.R. 2007. The intragenic approach as a new extension to traditional plant breeding. Trends in Plant Science 12: 
397-403.

Ronald, P. 2011. Plant genetics, sustainable agriculture and global food security. Genetics 188: 11-20.

Saalbach, I., Pickardt, T., Machemehl, F., Saalbach, G., Schieder, O. and Muntz, K. 1994. A chimeric gene encoding the methionine-rich $2 \mathrm{~S}$ albumin of the Brazil nut (Bertholletia excelsa H.B.K.) is stably expressed and inherited in transgenic grain legumes. Mol Gen Genet 242: 226-236.

Saathoff, A.J., Sarath, G., Chow, E.K., Dien, B.S. and Tobias, C.M. 2011. Downregulation of cinnamyl-alcohol dehydrogenase in switchgrass by RNA silencing results in enhanced glucose release after cellulase treatment. PLoS ONE 6: e16416. http://dx.doi.org/10.1371/journal.pone. 0016416.

Sandhu, S., Blount, A., Quesenberry, K. and Altpeter, F. 2010. Apomixis and ploidy barrier suppress pollenmediated gene flow in field grown transgenic turf and forage grass (Paspalum notatum). Theoretical and Applied Genetics 121: 919-929.

Schouten, H.J., Krens, F.A. and Jacobsen, E. 2006a. Cisgenic plants are similar to traditionally bred plants. EMBO Reports 7: 750-753.

Shotwell, M.A. and Larkins, B.A. 1989. The biochemistry and molecular biology of seed storage proteins. In: The Biochemistry of Plants. Marcus, A., Ed., Academic Press, San Diego, CA, pp. 297-345.

Somleva, M., Snell, K., Beaulieu, J., Peoples, O., Garrison, B. and Patterson, N. 2008. Production of polyhydroxybutyrate in switchgrass, a value-added co-product in an important lignocellulosic biomass crop. Plant Biotechnology Journal 6: 663-678.
Staswick, P.E. 1994. Storage proteins of vegetative plant tissues. Anual Rev Plant Physiol Plant Mol Biol 45: 303322.

Stewart, C.N. 2007. Biofuels and biocontainment. Nature Biotechnology 25: 283-284.

Tabe, L. M., Wardley-Richardson, T., Ceriotti, A., Aryan, A., McNabb, W., Moore, A. and Higgins, T.J.V. 1995. A biotechnological approach to improving the nutritive value of alfalfa. J Anim Sci 73: 2752-2759.

Tu Yi., Simone R., Zhiqian L., Yidong R., Megan G., Pieter, B., Gordon V.L., Marianne E.B., Kevin F.S., Joseph P.N., Aidyn M., German S. 2010. Functional analyses of caffeic acid Omethyltransferase and cinnamoylCoA-reductase genes from perennial ryegrass (Lolium perenne). The Plant Cell 22: 3357-3373.

Wandelt, C.I., Khan, M.R.I., Craig, S., Schroeder, H.E., Spencer, D. and Higgins, T.J.V. 1992. Vicilin with carboxy-terminal KDEL is retained in the endoplasmic reticulum and accumulates to high levels in the leaves of transgenic plants. Plant $\mathbf{J} 2$ : 181-192.

Wang, Z-Y. and Ge, Y. 2006. Recent advances in genetic transformation of forage and turf grasses. In vitro Cellular \& Developmental Biology Plant 42:1-18.

Wang, Z-Y., Takamizo, T., and Iglesias, V.A. 1992. Transgenic plants of tall fescue (Festuca arundinacea Schreb.) obtained by direct gene transfer to protoplasts. Nature Biotechnology 10: 691-696.

Wang, Z-Y., Ye, X.D., Nagel, J., Potrykus, I. and Spangenberg, G. 2001. Expression of a sulphur-rich sunflower albumin gene in transgenic tall fescue (Festuca arundinacea Schreb.) plants. Plant 
Cell Reports 20: 213-219.

Wang, Z-Y., Ge, Y.X., Scott, M. and Spangenberg, G. 2004a. Viability and longevity of pollen from transgenic and non-transgenic tall fescue (Festuca arundinacea) (Poaceae) plants. American Journal of Botany 91: 523-530.

Wu, Y.Y., Chenm Q.J., Chen, M., Chen, J., Wangler X.C. 2005. Salt-tolerant transgenic perennial ryegrass (Lolium perenne L.) obtained by Agrobacterium tumefaciens-mediated transformation of the vacuolar $\mathrm{Na}+\mathrm{H}+$ antiporter gene. Plant Science 169: 65-73.

Xiong, X., James, V., Zhang, H. and Altpeter, F. 2010. Constitutive expression of the barley HvWRKY38 transcription factor enhances drought tolerance in turf and forage grass (Paspalum notatum Flugge). Molecular Breeding 25: 419-432.

Xu, J.P., Schubert, J. and Altpeter, F. 2001. Dissection of RNA-mediated ryegrass mosaic virus resistance in fertile transgenic perennial ryegrass (Lolium perenne L.). Plant Journal 26: 265274.

Zhang, H., Lomba, P. and Altpeter, F. 2007. Improved turf quality of transgenic bahiagrass (Paspalum notatum Flugge) constitutively expressing the ATHB16 gene, a repressor of cell expansion. Molecular Breeding 20:415-423.

Zhang, J-Y., Broeckling, C., Sumner, L.W. and Wang, Z-Y. 2007. Heterologous expression of two Medicago truncatula putative ERF transcription factor genes, WXP1 and WXP2, in Arabidopsis led to increased leaf wax accumulation and Improved drought tolerance, but differential response in freezing tolerance. Plant Molecular Biology 64: 265-278.

Zhou, C., Han, L., Pislariu, C. 2011. From model to crop: functional analysis of a STAY-GREEN gene in the model legume Medicago truncatula and effective use of the gene for alfalfa (M. sativa) improvement. Plant Physiology 157: 1483-1496.

\section{How to cite this article:}

Rahul Kapoor, Tarvinder Pal Singh and Gaurav Khosla. 2018. Biotechnological Interventions in Forage Crops-A Review. Int.J.Curr.Microbiol.App.Sci. 7(07): 1229-1240.

doi: https://doi.org/10.20546/ijcmas.2018.707.148 